\title{
AGAMA DALAM PENDIDIKAN AGAMA ISLAM DI SEKOLAH DASAR
}

\author{
AKHMAD SHUNHAJI \\ Institut PTIQ Jakarta \\ akhmad.shunhaji09@gmail.com
}

\begin{abstract}
Abstrak
Tulisan ini mendiskripisikan tentang substansi moral dan etika sosial dalam mata pelajaran agama di sekolah. Objek kajian dalam tulisan ini adalah telaah kritis terhadap terhadap buku pendidikan agama Islam (PAI) dan budi pekerti (BP). Sementara metode yang digunakan dalam tulisan ini adalah metode studi pustaka (library research), yaitu melalui analisis deskriptif dengan cara mengumpulkan data, menyusun atau mengklarifikasi, menyusun dan menginterpretasinya sehingga akan mengarah pada hasil yang didapat. Tulisan ini memperlihatkan bahwa, jika materi Pendidikan Agama Islam bercorak Islam moderat, maka peserta didik dapat bersikap santun atau memiliki etika moral yang baik dan terbuka dalam menyikapi banyak pluralitas sosial. Disamping itu, peserta didik juga dapat memposisikan dirinya sebagai pribadi yang yang taat beragama dengan menjaga kemurnian akidah tetapi disaat yang sama dapat menghargai adat dan budaya lokal yang ada di lingkungan sekolah. Dengan mengejawantahkan Islam yang moderat, maka dapat dipastikan sikap spiritual peserta didik akan dapat semakin berkembang sesuai dengan perkembangan dan tuntutan zaman.
\end{abstract}

Kata Kunci: PAI, BP, Moderat, Spiritual, Etika Sosial

\begin{abstract}
This paper describes the moral substance and social ethics in religious subjects in schools. The object of study in this paper is a critical review of Islamic religious education books (PAI) and manners (BP). While the method used in this paper is library research method, namely through descriptive analysis by collecting data, compiling or clarifying, compiling and interpreting it so that it will lead to the results obtained. This paper shows that, if Islamic Religious Education material is of moderate Islamic style, students can be polite or have good moral ethics and are open in responding to many social pluralities. Besides that, students can also position themselves as religious devotees by maintaining the purity of the creed but at the same time being able to respect the local customs and culture in the school environment. By embodying a moderate Islam, it is certain that the spiritual attitude of students will be more developed in accordance with the development and demands of the times.

Keywords: PAI, BP, Moderate, Spiritual, Social Ethics
\end{abstract}




\section{A. PENDAHULUAN}

Agama masih dianggap sebagai bagian penting dalam pembentukan moral dan etika peserta didik di sekolah. Sekurang-kurangnya, terdapat dua alasan yang memperkuat anggapan demikian. Pertama, pendidik agama menjadi orang pertama yang dipersalahkan, ketika terdapat peserta didik yang melakukan kesalahan moral atau bertindak di luar batas etika kebaikan. Pendidik mata pelajaran Pendidikan Agama dianggap gagal mengajarkan agama kepada peserta didik. Kedua, mata pelajaran agama menjadi sentral pendidikan dalam aspek sikap spiritual dan aspek sikap sosial. Hal ini, ditandai dengan adanya pengalihan wewenang penuh kepada pendidik agama untuk menilai kedua kompetensi tersebut ${ }^{1}$. Pemberian wewenang ini, ditunjukkan oleh hasil revisi Kurikulum 2013 yang telah dirampungkan pada pertengahan tahun $2016^{2}$. Artinya, sikap spiritual dan sikap sosial peserta didik dikembangkan melalui pelajaran agama.

Revisi kurikulum berimplikasi pada hal lain yang terkait. Dalam aturan yang terkait dengan Kurikulum 2013, pendidikan agama merupakan bagian yang dipersiapkan oleh Pemerintah Pusat. Kurikulum, silabus, hingga buku pelajaran dipersiapkaan oleh Pemerintah Pusat. Penulisan buku pelajaran didasarkan pada silabus dan kurikulum. Oleh sebab itu, mengkaji buku-buku pelajaran Pendidikan Agama Islam dimungkinkan dapat memahami corak agama Islam yang diajarkan di sekolah melalui mata pelajaran Pendidikan Agama Islam.

\section{B. METODE}

Penelitian ini adalah penelitian kepustakaan (library research) dengan menggunakan metode analisis deskriptif, yaitu dengan jalan mengumpulkan data, menyusun atau mengklarifikasi, menyusun dan menginterpretasinya. ${ }^{3}$ Metode deskriptif yang dipilih karenapenelitian yang dilakukan bertujuan untuk menggambarkan dengan jelas tentang objek yang diteliti secara alamiah. ${ }^{4}$ Sementara itu, kajian deskriptif menurut Chaer, biasanya dilakukan terhadap struktur internal bahasa, yaitu struktur bunyi (fonologi), struktur kata (morfologi), srtuktur kalimat (sintaksis), struktur wacana, dan struktur semantik. Kajian deskriptif ini dilakukan dengan mula-mula mengumpulkan data, mengklasifikasi data, lalu merumuskan kaedah-kaedah terhadap keteraturan

1 Selain pendidik mata pelajaran agama, wewenang pemberi penilaian sikap sosial juga diberikan kepada pendidik mata pelajaran Pendidikan Pancasila dan Kewarganegaraan.

2 Nur Widiyanto, Revisi Kurikulum 2013, guru lebih dimudahkan, dalam www.kemdikbud.go.id diakses pada tanggal 14 Oktober 2019.

${ }^{3}$ Winarno Surakhmad, Pengantar Penelitian Ilmiah (Dasar, Metode dan Teknik), Bandung: Tarsito, 1980, h. 147.

${ }^{4}$ Fatimah T. Djajasudarma, Metode Linguistik Ancangan Metode Penelitian dan Kajian, Bandung: PT. Eresco. 1993, h. 8-9. 
yang terdapat pada keteraturan data itu khususnya kajian morfsintaksis. ${ }^{5}$ Kajian dimulai dengan merumuskan masalah, merumuskan fokus, kajian, atau mengajukan pertanyaan-pertanyaan kajian, dilanjutkan dengan pengumpulan data oleh peneliti sebagai instrumennya. Hasil yang dianalisis adalah bagaimana pembentukan moral dan etika peserta didik di sekolah melalui: 1) Pendidik atau guru agama Islam di sekolah; 2) Substansi mata pelajaran agama dalam membentuk sikap spiritual dan sosial peserta didik.

\section{HASIL DAN PEMBAHASAN}

\section{Hakikat Pendidikan Agama Islam di Indonesia}

Pendidikan agama Islam di sekolah memiliki peran penting dalam menyiapkan peserta didik di masyarakat. Masyarakat Indonesia, terlebih bagi pemeluk agama Islam adalah masyarakat religius. Agama menjadi bagian integral dalam kehidupannya. Momen-momen penting diintegrasikan dengan ritual keagamaan, seperti pernikahan, kematian, dan lain-lain. Oleh karenanya, pendidikan agama Islam di sekolah, dimungkinkan menjadi bagian penting dalam mempersiapkan masyarakat Indonesia yang tetap religius.

Pendidikan Agama Islam di sekolah menjadi bagian dari sistem pendidikan nasional. Penyelenggaraannya dilandasi oleh aturan dalam UU Sisdiknas Nomor 20 Tahun 2003. Dalam UU tersebut, dinyatakan bahwa pendidikan nasional adalah pendidikan yang berdasarkan Pancasila dan UUD 1945 yang berakar pada nilai-nilai agama, kebudayaan nasional Indonesia dan tanggap terhadap tuntutan perubahan zaman ${ }^{6}$.

Dalam kalimat UU Sisdiknas tersebut, dapat dipahami bahwa agama adalah bagian dari akar pendidikan nasional. Artinya, agama harus menjadi bagian penting yang mewarnai iklim dan kultur pendidikan formal dalam semua jenjang pendidikan dari sekolah dasar hingga jenjang sekolah menengah atas atau pun sekolah menengah kejuruan bahkan di pendidikan tinggi. Kehidupan yang berjalan di sekolah-sekolah harus berakar pada nilai-nilai agama.

Agama diharapkan menjadi bagian yang ikut mewarnai iklim dan kultur sekolah. Oleh karenanya, agama dipelajari dan dipraktikkan di sekolah. Sekolah - sekolah, baik negeri maupun swasta, terkena kewajiban untuk memberikan pelajaran pendidikan agama di sekolah. Semua peserta didik diberikan haknya untuk menerima pelajaran pendidikan agama di sekolah. Peserta didik Muslim disadarkan untuk belajar beragama di sekolah melalui pelajaran Pendidikan Agama Islam.

${ }^{5}$ Abdul Chaer, Kajian Bahasa: Struktur Internal, Pemakaian, dan Pembelajaran, Jakarta: Rineka Cipta, 2007, h. 9.

${ }^{6}$ Dewan Perwakilan Rakyat, Undang-Undang Sistem Pendidikan Nasional Nomor 20 Tahun 2003, dalam Undang-Undang Sistem Pendidikan Nasional, Jakarta: Permata Press, 2013, h. 3. 
Pendidikan agama di sekolah, diharapkan memberikan kontribusi positif dalam membentuk warga negara yang beragama. Walaupun penduduk Indonesia memeluk agama sesuai dengan keyakinannya masing-masing, bukan berarti bangsa Indonesia adalah negara agama. Sebaliknya, agama di Indonesia juga bukan agama negara. Negara dan agama memiliki hubungan yang sangat erat. Menurut profesor Nasaruddin Umar ${ }^{7}$, negara agama adalah negara yang menjadikan salah satu agama sebagai hukum dasar dalam menata dan menyelesaikan masalah kehidupan berbangsa dan bernegara seperti Saudi Arabia, Kuwait, Syiria, dan Vatikan. Hubungan antara agama dan negara nampak jelas menunjukkan adanya hubungan formal. Di negara-negara yang antara agama dan negara memiliki hubungan formal biasanya ditunjukkan oleh adanya formalisasi hubungan keduanya dalam sistem pemerintahan. Agama secara resmi dijadikan landasan konstitusi.

Selain hubungan formal, pada suatu negara mungkin menempatkan pada pemisahan negara dan agama. Negara tidak memiliki hubungan sama sekali dengan agama. Antara negara dan agama masing-masing berjalan sendirisendiri. Ikatan keduanya sama sekali terputus. Sistem pemerintahan pada negara seperti ini tidak memberikan peluang pada agama untuk melakukan campur tangan urusan kenegaraan dan sistem politik. Pemerintah dijalankan tanpa melibatkan peran agama sama sekali. Pemerintahan dijalankan berdasarkan pada undang-undang kenegaraan yang disepakati berlakunya. Negara-negara seperti ini disebut sebagai negara sekuler ${ }^{8}$.

Terkait dengan hubungan negara dan agama dipandang dari perspektif religio- political power, Keith A.Roberts membedakannya menjadi tiga macam. Pertama, unified paradigm yaitu adanya integrasi antara negara dan agama. Negara merupakan wilayah agama dan sebaliknya. Dengan demikian, kepala negara adalah pimpinan negara dan pimpinan agama. Kedua, symbiotic paradigm, hubungan antara negara dan agama saling membutuhkan. Keduanya, negara dan agama, memiliki hubungan timbal balik yang positif. Ketiga, secularistic paradigm, negara dan agama tidak memiliki hubungan sama sekali. Negara dijalankan tanpa pengaruh agama apapun. Demikian halnya, agama juga tidak memiliki payung hukum ataupun lembaga yang diakui secara resmi oleh negara9.

Berbeda dengan negara agama adalah agama negara. Malaysia adalah salah satu contoh negara yang memiliki agama negara. Agama negara menurut

7 Nasaruddin Umar, Antara Negara dan Agama, dalam www.kemenag.go.id diakses pada tanggal 16 Oktober 2019 pukul 14.18 WIB.

8 Abdur Rahman Mas'ud dan A.Salim Ruhana, Kompilasi Kebijakan dan Peraturan PerundangUndangan Kerukunan Umat beragama, Edisi ke-11, Jakarta: Puslitbang Kehidupan Keagamaan, 2009, h.13.

${ }^{9}$ Keith A. Roberts, Religion in Sociological Perspective, Fifth Edition, USA: SAGE Publications, Inc, 2012, h. 251. 
profesor Nasaruddin Umar ${ }^{10}$ merupakan sebuah klaim dari suatu negara terhadap agama tertentu sebagai agama resmi negara tersebut. Agama berfungsi sebagai agama resmi untuk kepentingan seremonial dan bukan digunakan sepenuhnya dalam rujukan keputusan hukum dan perundang-undangan yang tentunya tidak bertentangan dengan ajaran agama yang diakui.

Paparan di atas menggambarkan bahwa terdapat tiga tipologi hubungan negara dan agama. Pertama, hubungan yang terpisah antara negara dan agama. Agama tidak memiliki poros hubungan konstitusional, struktural, maupun fungsional dengan negara. Kedua, negara memiliki hubungan formal dengan agama. Dan sebaliknya, agama memiliki hubungan formal dengan negara. Negara mengakui agama sebagai dasar negara dan konstitusinya. Sistem, pola, dan bentuk negara berbasis pada agama. Ketiga, negara dan agama tidak memiliki hubungan formal tetapi hubungan keduanya sangat erat. Para pemeluk agama diakui dan dilindungi oleh negara dalam menjalankan perintah agama dan keyakinannya.

Indonesia bukan negara agama, dan agama yang berkembang di Indonesia juga bukan agama negara. Indonesia juga bukan negara sekuler yang menyerahkan urusan pemerintahan kepada para eksekutif pemerintah dan urusan agama kepada pemimpin agama. Indonesia adalah negara Pancasila yang memiliki memiliki lima sila, di antaranya Ketuhanan Yang Maha Esa. Indonesia tidak memiliki agama khusus sebagai agama resmi dalam menjalankan roda pemerintahan ataupun dasar untuk memutuskan hukum.

Walaupun demikian, Indonesia mengakui agama-agama yang dipeluk oleh warganya. Bahkan memeluk agama dan beribadat menurut agamanya adalah bagian dari hak asasi yang diakui secara sah oleh negara. Hal ini tertulis di dalam UUD 1945 pasal 28E ayat (1), "Setiap orang berhak memeluk agama dan beribadat menurut agamanya, memilih pendidikan dan pengajaran, memilih pekerjaan, memilih kewarganegaraan, memilih tempat tinggal di wilayah negara dan meninggalkannya, serta berhak kembali"11.

Dari pernyataan yang tersurat dalam UUD 1945, bahkan mengandung sebuah perintah secara implisit bahwa setiap warga negara harus memiliki agama dan beribadah sesuai dengan agamanya. Istilah setiap orang berhak memeluk agama dan beribadat menurut agamanya, mengandung makna adanya kebebasan setiap pribadi untuk memeluk agama, bukan tanpa agama. Oleh karena itu, kalimat berikutnya kemudian menjelaskan kebebasan untuk beribadah menurut agama yang diyakininya itu. Untuk tujuan tersebut maka

10 Nasruddin Umar, Antara Negara dan Agama, dalam www.kemenag.go.id, diakses pada tanggal 16 Oktober 2019 pukul 14.18 WIB. (Lihat juga: Puslitbang Kehidupan Keagamaan Badan Litbang dan Diklat Departemen Agama Republik Indonesia, Kompilasi Kebijakan dan Peraturan Perundang-Undangan Kerukunan Umat Beragama, Edisi Kesebelas, Jakarta: Puslitbang Kehidupan Keagamaan, 2009, h. 14-15)

11 Majelis Permusyawaratan rakyat, Panduan Pemasyarakatan Undang-Undang Dasar Negara Republik Indonesia Tahun 1945, Jakarta: Sekretariat Jenderal MPR RI, 2006, h.113. 
sekolah sebagai lembaga yang melakukan pendidikan dan pengajaran perlu memfasilitasi untuk mengajarkan pendidikan agama dan cara beribadah menurut agamanya. Peserta didik Muslim seharusnya difasilitasi untuk memperoleh pendidikan agama Islam dan beribadah sesuai ajaran agama Islam.

Paparan di atas, memberikan gambaran sederhana bahwa pendidikan agama Islam merupakan bagian penting dalam kehidupan di sekolah. Pendidikan agama Islam digambarkan oleh fungsinya di atas, menyentuh pada aspek sikap dan tata nilai, baik ritual maupun sosial. Pendidikan agama Islam diartikan sebagai upaya sadar yang dilakukan oleh orang-orang yang memiliki tanggungjawab terhadap pembinaan, bimbingan, pengembangan, serta pengarahan potensi yang dimiliki anak agar mereka dapat berfungsi dan berperan sebagaimana hakekat kejadiannya ${ }^{12}$. Dalam pengertian ini, tergambar bahwa pelaksanaan pendidikan agama Islam menjadi tanggungjawab banyak orang dalam berbagai instansi, bukan terbatas pada sekolah.

Pendidikan agama Islam di sekolah diarahkan pada pembentukan pribadi peserta didik sebagai Muslim yang utuh. Pendidikan agama Islam dalam lembaga pendidikan umum merupakan suatu pembinaan terhadap peserta didik agar berkepribadian utuh, menjadi ilmuan yang beriman dan bertakwa kepada Allah SWT, mampu mengabdikan ilmunya untuk kesejahteraan umat manusia ${ }^{13}$. Dalam konteks yang demikian, pendidikan agama Islam di sekolah ataupun lembaga pendidikan umum yang lain berfungsi menyiapkan generasi Muslim yang berkemajuan bukan menjadi genarasi ahli dalam bidang agama Islam.

Dalam pandangan demikian, pendidikan agama Islam di Indonesia diarahkan pada dua dampak hasil pembelajaran (learning outcome). Pertama, pendidikan agama Islam diselenggarakan untuk membentuk pribadi peserta didik memahami, mengerti, dan mampu mengamalkan ajaran Islam (actual outcome). Kedua, pendidakan agama Islam diarahkan pada kemampuan untuk menyiapkan peserta didik sebagai anggota masyarakat religius (desired outcome). Kedua hasil pembelajaran ini sudah selayaknya menjadi perhatian seluruh stakeholder sekolah, mulai dari perencanaan, pelaksankaan, hingga evaluasi.

\section{Sejarah Kebijakan Pendidikan Agama Islam di Sekolah Dasar}

Pada jenjang sekolah dasar, pendidikan agama Islam memperoleh perhatian sejak awal Indonesia berdiri. Pendidikan agama, termasuk di dalamnya pendidikan agama Islam, diberikan ruang untuk dipelajari di sekolah. Sejak masa orde lama, Presiden Sukarno mengeluarkan kebijakan pendidikan dalam bentuk undang-undang yaitu UU Nomor 4 Tahun 1950 tentang Pendidikan dan Pengajaran. UU ini kemudian dinyatakan berlakunya di seluruh

12 Imam Mohtar, Problematikan Pembinaan Pendidikan Agama Islam pada Masyarakat, Ponorogo: Uwais Inspirasi Indonesia, 2017, h. 47.

13 Akhmad Shunhaji, Implementasi Pendidikan Agama di Sekolah Katolik Kota Blitar dan Dampaknya terhadap interaksi Sosial, Yogyakarta: Aynat Publishing, 2017, h. 160. 
Indonesia melalui UU Nomor 12 Tahun 1954. Dalam menetapkan sebuah kebijakan tidak terlepas dari aspek politik dan kekuatan kekuasaan pada saat kebijakan dikeluarkan. Demikian pula munculnya UU Nomor 4 Tahun 1950 dan UU Nomor 12 Tahun 1954 juga kental dengan tarik menarik kepentingan politik dan dalam menentukan kebijakan termasuk kebijakan pendidikan. Partai politik pada saat itu terpecah menjadi 2 kekuatan yang saling berpolemik yaitu kekuatan nasionalis Islamis dan kekuatan kelompok nasionalis sekuler ${ }^{14}$.

Kekuatan kelompok yang masuk dalam kelompok nasionalis Islamis adalah Masyumi, PSII, NU, sedangkan pada kekuatan kelompok nasionalis ada Partai Nasional Indonesia dan nasionalis sekuler yang terdiri dari Partai Sosialis Indonesia, PKI, Parkindo, dan Partai Murba ${ }^{15}$. Kedua kekuatan besar ini saling tarik menarik kepentingan dalam merumuskan dan menentukan kebijakankebijakan yang akan ditetapkan oleh pemerintah termasuk kebijakan pendidikan.

Dalam proses tarik menarik ini, hasil kebijakan terlihat bahwa pemikiranpemikiran kelompok tertentu mendominasi hasil kebijakan. Karena kedua kekuatan sama-sama kuat maka pengambilan keputusan cukup pelik. Masingmasing kelompok menginginkan agar keputusan yang diambil dapat mengakomodir kepentingan kelompoknya.

Ketetapan Majelis Permusyawaratan Rakyat Sementara (MPRS) ${ }^{16}$ Republik Indonesia Nomor II/MPRS/1960 tentang Garis-Garis Besar Pola Pembangunan Nasional Semesta Berencana Tahap Pertama 1961-1969, Bab II tentang Ketentuan Umum, pasal 2 yang mengatur bidang mental, agama, kerohanian, dan penelitian, antara lain menjelaskan dalam poin pertama melaksanakan Manifesto Politik di lapangan pembinaan Mental/Agama/ Kerohanian dan Kebudayaan dengan menjamin syarat-syarat spiritual dan material agar setiap warga negara dapat mengembangkan kepribadiannya dan kebudayaan Nasional Indonesia serta menolak pengaruh-pengaruh buruk kebudayaan asing.

14 Hamlan Andi Baso Malla, "Kajian Sosio Historis Tentang Politik Kebijakan Pendidikan Islam di Indonesia", Inspirasi, Nomor XIV Edisi Oktober 2011, h. 54.

15 Ahmad Syafi'i Maarif, Islam dan Politik: Teori Belah Bambu Masa Demokrasi Terpimpin 19591965, Jakarta: Gema Insani, 1996.

${ }^{16}$ MPRS memiliki fungsi layaknya MPR yang ada pada UUD 1945 karena MPRS merupakan cikal bakal MPR. Namun MPRS pertama kali dibentuk pada saat negara dalam keadaan darurat berdasarkan Dekrit Presiden 5 Juli 1959. Oleh karenanya, Pada masa ini, MPRS sangat dipengaruhi oleh Presiden, mulai dari jumlah anggota hingga pengangkatan pimpinan. Ketua MPRS Pertama adalah Chaerul Saleh. Ketetapan MPRS Nomor II/MPRS/1960 ini adalah salah satu produk yang dihasilkannya. Namun, MPRS bukanlah selamanya dipengaruhi oleh kekuasaan Presiden secara mutlak karena MPRS terbagi menjadi dua masa yaitu masa Demokrasi Terpimpin (periode 1960-1965) dan Demokrasi Pancasila (1966-1972). MPRS masa Demokrasi Pancasila menghasilkan keputusankeputusan yang lebih demokratis, terlepas dari pengaruh kekuasaan mutlak dari Presiden sehingga bisa menjadi lembaga yang memberikan pemikiran lebih obyektif. (keterangan serupa dapat dilihat: Miriam Budiardjo, dkk, Dasar-Dasar Ilmu Politik, Jakarta: Gramedia Pustaka Utama, 2003, h.201-203). 
Poin ketiga dalam ketetapan tersebut berbunyi menetapkan pendidikan agama menjadi mata pelajaran di sekolah-sekolah mulai dari sekolah rakyat sampai dengan universitas-universitas Negeri dengan pengertian bahwa muridmurid berhak tidak ikut serta, apabila wali murid/murid dewasa menyatakan keberatannya ${ }^{17}$. Keputusan ini menetapkan pemberian pendidikan agama Islam semenjak tingkat sekolah rakyat (saat ini sekolah dasar) hingga perpendidikan tinggi walaupun terdapat syarat bagi peserta didik yang mengikutinya. Untuk peserta didik pada tingkat sekolah dasar diberikan syarat ijin dari orang tuanya. Peserta didik dapat mengikuti pendidikan agama jika peserta didik tersebut diperbolehkan untuk mengikuti pendidikan agama di sekolah. Peserta didik berhak untuk tidak mengikuti pendidikan agama jika orang tua atau walinya menyatakan keberatan untuk anaknya mengikuti pelajaran agama di sekolah.

Konsep ini menggambarkan adanya demokratisasi pendidikan, seandainya seorang peserta didik diberikan pilihan dalam mengikuti semua mata pelajaran. Setiap pribadi berhak memilih untuk mengikuti suatu pelajaran dan tidak mengikuti pelajaran yang lain. Dalam konsep pendidikan, tindakan memberikan kesempatan kepada peserta didik ini sejalan dengan konsep Carl Roger yang lebih menekankan pada hasil pendidikan sebagai aktualisasi.

Menurut pendapat Carl Roger, tujuan pendidikan adalah melahirkan pribadi yang mampu mengaktualisasikan diri memilih segala hal yang terkait dengan pengembangan dirinya ${ }^{18}$. Tetapi dalam kasus ini sekurang-kurang terdapat dua hal yang mendasari bahwa kebijakan untuk syarat pemberian ijin orang tua dalam hal mengikuti pelajaran agama, bukanlah sesuai dengan pendapat Roger, yaitu: pertama, peserta didik tidak diberikan hak memilih untuk mengikuti pelajaran atau tidak mengikuti pelajaran, melainkan orang tua siswa yang diberikan hak untuk memberikan ijin atau tidak kepada anak-anaknya dalam hal mengikuti pelajaran pendidikan agama. Kedua, mata Pelajaran yang bersyarat hanya khusus mata pelajaran Pendidikan Agama Islam.

Dengan demikian, dapat dipahami bahwa kebijakan pendidikan yang menjadi hasil ketatapan MPRS lebih dominan sebagai hasil kebijakan politik pendidikan. Kebijakan-kebijakan yang dihasilkan tidak dapat dipisahkan dari proses politik yang berkembang dalam lingkup lembaga negara ini.

Sebagai implementasi dari ketetapan MPRS Nomor II tahun1960 ini, Presiden mengeluarkan Penetapan Presiden Nomor 19 Tahun 1965 Tentang Pokok-Pokok Sistem Pendidikan Nasional Pancasila. Dalam PP Nomor 19 tersebut mendefinisikan pendidikan nasional Indonesia sebagai pendidikan yang

${ }^{17}$ Majelis Permusyawaratan Rakyat Sementara (MPRS) Republik Indonesia: “Ketetapan MPRS RI Nomor II/MPRS/1960 tentang Garis-Garis Besar Pola Pembangunan Nasional Semesta Berencana Tahap Pertama 1961-1969, Bab II tentang Ketentuan Umum, pasal 2 yang mengatur Bidang Mental, Agama, Kerohanian, dan Penelitian, Bandung: Sekretariat MPRS RI, 1960, h. 3-4.

18 Joy A. Palmer (ed), 50 Pemikir Pendidikan: dari Piaget sampai Masa Sekarang, diterjemahkan oleh Farid Assifa dari judul Fifty Modern Thinkers on Education, Yogyakarta: Jendela, 2003, h. 92. 
membina masyarakat Indonesia menjadi manusia yang berjiwa Pancasila dan Manipol/Usdek. Dalam PP tersebut disampaikan sebagai berikut: Pendidikan Nasional Indonesia, ialah pendidikan yang baik materiil maupun spiritual membina manusia dan Bangsa Sosialis Indonesia yang berjiwa PancasilaManipol/Usdek sanggup menyelesaikan ketiga kerangka tujuan revolusi Indonesia sesuai dengan Manipol, yaitu: Pertama, Pembentukan satu Negara Republik Indonesia yang berbentuk Negara-Kesatuan dan Negara-Kebangsaan, yang demokratis, dengan wilayah kekuasaan dari Sabang sampai Merauke; Kedua, Pembentukan satu masyarakat yang adil dan makmur materiil dan spiritual dalam wadah Negara Kesatuan Republik Indonesia itu; Ketiga, Pembentukan satu persahabatan yang baik antara Republik Indonesia dan semua negara didunia terutama sekali dengan negara-negara Asia-Afrika, atas dasar hormat-menghormati satu sama lain, dan atas dasar kerja sama membentuk satu Dunia yang bersih dari imperialisme dan kolonialisme, menuju kepada Perdamaian Dunia yang sempurna". ${ }^{19}$

Kebijakan pendidikan pada Orde Lama menjadikan pembinaan manusia berdampingan dengan pembinaan bangsa yang sosialis. Ini sebagai produk kebijakan pendidikan Orde Lama yang diwarnai oleh partai-partai politik yang dominan dan lebih dekat pada kekuasaan pada saat itu. Demikianlah bahwa Pendidikan Nasional Indonesia pada kebijakan Orde Lama didefinisikan sebagai proses mendidik pada peserta didik baik materiil maupun spiritual sebagai proses membina manusia dan Bangsa Sosialis Indonesia agar memiliki jiwa Pancasila-Manipol/Usdek sanggup menyelesaikan ketiga kerangka tujuan revolusi Indonesia sesuai dengan Manipol.

Kebijakan pendidikan pada Orde Baru berbeda dengan kebijakan pendidikan masa Orde Lama. Jika Orde Lama merupakan sebutan untuk masa pemerintahan Presiden Sukarno, maka Orde Baru adalah sebutan bagi masa pemerintahan Presiden Suharto. Pergantian presiden dari presiden Sukarno kepada presiden Suharto melalui proses politik di MPRS. Pergantian presiden diawali dengan pergantian ketua MPRS dan AH Nasution terpilih menjadi Ketua MPRS dan lantik pada tanggal 12 Juni 1966. Tanggal 22 Juni 1966, Presiden Sukarno berpidato Nawaksara di depan sidang umum IV/MPRS, saat itulah mulai terjadi perubahan politik. MPRS menolak pidato Nawaksara Presiden Sukarno. Penolakan ini menurut MPRS disebabkan ketidakpuasan MPRS terhadap isi pidato presiden. Pidato presiden Sukarno dianggap tidak mencerminkan pertanggungjawaban yang lengkap mengenai kemunduran

${ }_{19}$ Menteri Sekretaris Negara, Lembaran Negara: "Penetapan Presiden Republik Indonesia Nomor 19 Tahun 1965" Tentang Pokok-Pokok Sistem Pendidikan Nasional Pancasila, dalam dapp.bappenas.go.id, diakses pada tanggal 14 Oktober 2019 pukul 22.35WIB. 
ekonomi, akhlak, dan G30S/PKI ${ }^{20}$. Ketidakpuasan anggota sidang MPRS memberikan dampak yang signifikan terhadap kepemimpinan Sukarno.

Presiden Sukarno akhirnya dicabut kekuasaannya sebagai presiden oleh MPRS melalui Ketetapaan MPRS RI Nomor XXXIII/MPRS/1967. Berhentinya Sukarno sebagai Presiden, selanjutnya kursi kepesidenan diberikan kepada Suharto. Sejak pergantian presiden inilah maka orde lama sudah selesai dan mulailah Orde Baru. Perubahan situasi politik dan para pemangku kebijakannya, memberikan perubahan pula terhadap kebijakan pendidikan.

Pemerintah Orde Baru didukung kekuatan militer sehingga presiden dapat memperketat garis komando dan kendali. Muncullah sentralisasi kewenangan pada pemerintah atau presiden. Demikian dipaparkan oleh Haligan dan Turner, bahwa kekuatan militer yang menjadi sumber utama kekuasaan Presiden Suharto sangat membantu penerapan sentralistik dari seluruh kepulauan di Indonesia ${ }^{21}$.

Kondisi ini mengarahkan pada kebijakan pendidikan di Indonesia ke arah sentralistik. Kebijakan segala bidang termasuk kebijakan pendidikan selalu dikontrol pemerintah pusat. Intervensi pemerintah pusat yang terlalu dominan menghasilkan kebijakan negara dalam Undang-Undang Sisdiknas yang isinya didominasi kepentingan pemerintah pusat ${ }^{22}$. Padahal, dalam realita kehidupan berbangsa dan bernegara, masyarakat Indonesia sangat beragam. Kepentingan masyarakat Indonesia yang beragam belum semuanya terakomodir. Jika kepentingan pemerintah pusat yang dominan dalam merancang dan menetapkan isi kebijakan pendidikan, bisa jadi hasil dari kebijakan tersebut hanya memenuhi kebutuhan sebagian masyarakat dan belum dapat memenuhi kebutuhan masyarakat banyak.

Dalam tataran operasional, Mastuhu menyimpulkan bahwa politik kebijakan pendidikan pada masa Orde Baru, sekurang-kurangnya terdapat tiga hal yang pada praktiknya dapat dirasakan oleh masyarakat. Ketiga hal tersebut adalah sentralisasi sistem pendidikan, diskriminasi antara sekolah negeri dan swasta, serta ketatnya sistem administrasi ${ }^{23}$. Sistem pendidikan tersentral di pemerintah pusat sehingga memungkinkan adanya keterlambatan pengambilan kebijakan yang sifatnya mendesak karena harus melalui birokrasi yang cukup panjang.

Sentralisasi sistem pendidikan ditunjukkan oleh adanya pengaturan kerja pendidikan secara otoritatif dari pemerintah pusat sampai ke daerah-daerah

20 www.Tempo.co.id, "wawancara Abdul Haris Nasution":saya ini 21 tahun dicekal, diakses pada 13 Oktober 2019 pukul 20.14 WIB.

21 Haligan dan Turner, Profile of Government Administration in Asia, Canberra: Australia Government Publishing Service, 1995, h. 38.

${ }_{22}$ Hamlan Andi Baso Malla, "Kajian Sosio Historis Tentang Politik Kebijakan Pendidikan Islam di Indonesia" ... h. 57.

${ }_{23}$ Mastuhu, Menata Ulang Pemikiran Sistem Pendidikan Nasional dalam Abad 21, Yogyakarta: SIP dan MSI UII, 2003, h. 23. 
bahkan hingga ke sekolah-sekolah terkait dengan kurikulum, metode dan materi ajar, tenaga kependidikan, hingga ijazah. Diskriminasi sekolah negeri dan swasta juga dirasakan oleh sekolah-sekolah keagamaan. Diskriminasi dapat dirasakan pada pendanaan, pemberian fasilitas, hingga pengakuan ijazah. Semua diatur oleh pemerintah bukan oleh sekolah penerima. Sedangkan ketatnya sistem administrasi ditunjukkan adanya otoritas kekuasaan bahkan pada tingkat sekolah.

Sekalipun demikian, penataan pendidikan di Indonesia dirasa semakin baik. Kebijakan yang dihasilkan lebih memihak pada keragaman masyarakat dibanding masa pemerintahan sebelumnya. Pada masa Orde Baru lahirlah Sisdiknas Nomor 2 Tahun 1989. Dalam UU Sistem Pendidikan Nasional ini, pendidikan nasional didefinisikan sebagai pendidikan yang berakar pada kebudayaan bangsa Indonesia dan yang berdasarkan Pancasila dan UndangUndang Dasar 1945. Dalam pasal (3) juga dijelaskan bahwa fungsi pendidikan nasional adalah untuk mengembangkan kemampuan serta meningkatkan mutu kehidupan dan martabat manusia Indonesia dalam rangka upaya mewujudkan tujuan nasional ${ }^{24}$.

Jika dicermati lebih mendalam, maka sistem pendidikan nasional pada masa Orde Baru ini menghilangkan kata 'sosialis' seperti yang tertuang dalam UUSPN masa Orde Lama. Ini berarti bahwa ideologi komunis yang mewarnai kebijakan-kebijakan Orde Lama juga sudah tidak digunakan. Pendidikan kebangsaan benar-benar dilandaskan pada Pancasila dan UUD 1945. Hal ini tidak terlepas dari kebijakan-kebijakan politik dan pemangku kepentingan.

Pada masa Orde Baru yang dimulai dari rapat MPRS ${ }^{25}$ pada tahun 1966 sudah nampak perbedaan yang signifikan. MPRS menetapkan suatu Ketetapan MPRS yang mengatur tentang agama dan pendidikan. Ketetapan tersebut adalah Ketetapan MPRS RI Nomor XXVII/MPRS/1966 tentang agama, pendidikan, dan kebudayaan. Pada bab pertama pasal (1) ketetapan MPRS tersebut menetapkan suatu perubahan terhadap ketetapan MPRS Nomor II/MPRS/1960 bab kedua pasal (2) ayat (3) yang menjelaskan adanya penghapusan kata bahwa "muridmurid berhak tidak ikut serta, apabila wali murid atau murid dewasa menyatakan keberatannya". Kalimat ini dirubah menjadi "menetapkan pendidikan agama menjadi mata pelajaran di sekolah-sekolah mulai dari sekolah dasar sampai dengan universitas-universitas negeri" ${ }^{26}$. Inilah perbedaan yang benar-benar bertolak belakang dengan kebijakan pemerintah sebelumya.

${ }^{24}$ Dewan Perwakilan Rakyat, Undang-undang RI Nomor 2 Tahun 1989 tentang Sistem Pendidikan Nasional, dalam Undang-undang RI Nomor 2 Tahun 1989, Jakarta: Bp Tjipta Karya, 1989, h. 3.

${ }^{25}$ MPRS ini berbeda dengan MPRS periode sebelumnya. MPRS periode ini masuk pada masa periode Demokrasi Pancasila sebagai penyempurnaan dari MPRS periode sebelumnya yang terkena pengaruh gerakan komunis. Pimpinan MPRS periode ini adalah Dr.A.H. Nasution sebagai ketua, dan wakil-wakilnya adalah Osa Maliki, H.M Subchan Z.E, M.Siregar, dan Mashudi.

${ }^{26}$ Majelis Permusyawaratan Rakyat Sementara (MPRS) Republik Indonesia: “Ketetapan MPRS RI Nomor II/MPRS/1960 ... h. 1. 
Awal masa pemerintahan Orde Baru mengubah kedudukan pendidikan agama yang diberlakukan di Indonesia. Pendidikan Agama menjadi pendidikan wajib yang harus diikuti setiap peserta didik di sekolah umum. Berbeda dengan pemerintah Orde Lama di mana pelajaran Pendidikan Agama diserahkan pilihannya kepada orang tua ataupun peserta didik dewasa, pada masa Orde Baru tersebut kebijakan pendidikan agama menjadi mata pelajaran yang disejajarkan dengan mata pelajaran wajib yang lain seperti Pendidikan Moral Pancasil dan Bahasa Indonesia.

Kebijakan pendidikan masa Orde Baru ini kemudian diwujudkan di dalam bentuk susunan Undang-Undang Sisdidknas Nomor 2 yang dikeluarkan pada Tahun 1989 yang menuangkan tujuan pendidikan nasional. Dalam UU Sisdiknas tersebut dijelaskan bahwa pendidikan nasional bertujuan untuk:

"Mencerdaskan kehidupan bangsa dan mengembangkan manusia Indonesia seutuhnya, yaitu manusia yang beriman dan bertaqwa terhadap Tuhan YME dan budi pekerti luhur, memiliki pengetahuan dan ketrampilan, kesehatan jasmani dan rohani, kepribadian yang mantap dan mandiri serta rasa tanggungjawab kemasyarakatan dan kebangsaan". ${ }^{27}$

Seperti yang dijelaskan di atas bahwa pendidikan nasional bertujuan untuk mencerdaskan kehidupan bangsa melalui pengembangan setiap pribadi rakyatnya. Logikanya, jika setiap pribadi masyarakatnya memiliki kualitas yang baik maka bangsa Indonesia akan meningkat kualitasnya menjadi lebih baik pula. Peningkatan pribadi dari warga masyarakat akan berdampak positif terhadap kehidupan bangsa jika pribadi tersebut meningkat secara utuh. Pribadipribadi yang berkualitas dan berkembang seutuhnya. Berkembang secara individu sebagai manusia seutuhnya.

Istilah manusia seutuhnya sudah digunakan pada masa Orde Baru ini. Manusia seutuhnya dapat dipahami sebagai manusia yang memiliki perkembangan kemampuan positif sebagai manusia beriman yang bermanfaat bagi lingkungan. Manusia seutuhnya tersebut, jika dipandang dari sisi akidah, manusia seutuhnya memiliki keimanan kepada Tuhan Yang Maha Esa, dipandang dari sisi moral, memiliki budi pekerti yang luhur, dan dipandang dari sisi pengembangan akal, memiliki pengetahuan dan ketrampilan.

Perubahan-perubahan kebijakan pendidikan nasional pada era Orde Baru terus berkembang menuju arah perbaikan dan keberpihakan terhadap keragaman masyarakat. Komitmen ini seolah-olah semakin kuat menjadi komitmen bersama dari para pemegang kepentingan di pemerintahan dan juga DPR.

27 Dewan Perwakilan Rakyat, Undang-Undang Republik Indonesia Nomor 2 Tahun 1989 tentang Sistem Pendidikan Nasional dalam Undang-Undang Sistem Pendidikan Nasional, Jakarta: Bp Tjipta Karya, 1989, h. 4. 
Berakhirnya masa Orde Baru, berganti dengan masa Reformasi yang dimulai pada tahun 1998. Di masa Reformasi, kebebebasan berpendapat, demokratisasi, dan otonomi daerah menjadi ciri khasnya. Sehingga muncul berbagai kebijakan politik, di antaranya Undang-Undang Nomor 22 Tahun 1999 tentang pemerintah daerah yang dituangkan pada lembaran negara Republik Indonesia Tahun 1999 Nomor 60. Undang-undang ini kemudian disempurnakan dengan UU Nomor 32 Tahun 2004 tentang pemerintahan daerah, yang juga memberikan hak pengaturan pendidikan oleh daerah.

Berbagai Undang-undang telah dikeluarkan pada masa itu, termasuk UU Sisdiknas Nomor 20 Tahun 2003. Undang-undang ini lebih mempertimbangkan penyempurnaan dan memasukkan hasil evaluasi dari undang-undang sebelumnya yang menginginkan agar sistem pendidikan nasional harus lebih mampu menjamin relevansi, efisiensi manajemen pendidikan, pemerataan kesempatan pendidikan, serta peningkatan mutu pendidikan sesuai tuntutan kehidupan lokal, nasional, dan internasional ${ }^{28}$.

Dalam penyempurnaan sistem pendidikan, perhatian terhadap pendidikan akhlak lebih nampak. Fungsi pendidikan sebagai pembentuk watak dan karakter peserta didik. Ini sesuai dengan jiwa masyarakat Indonesia. Masyarakat Indonesia merupakan masyarakat yang memiliki moral dan sopan santun. Penyempurnaan undang-undang sistem pendidikan ini juga sesuai karakter bangsa yang mengakui adanya moral agama. Implikasi dari perkembangan peraturan ini, pendidikan agama, termasuk di dalamnya pendidikan agama Islam, ditambah pembahasannya menjadi pendidikan agama dan budi pekerti.

\section{Pendidikan Agam Islam pada Jenjang Sekolah Dasar}

Jenjang sekolah dasar menjadi pondasi awal dalam mengenalkan secara formal pendidikan agama Islam di sekolah. Dalam Undang-Undang Sisdiknas Nomor 20 Tahun 2003, memang disebutkan adanya jenjang sekolah sebelum sekolah dasar. Pendidikan itu disebut dengan jenjang pendidikan anak usia dini. Dalam pasal 28 (1) disebutkan bahwa pendidikan anak usia dini diselenggarakan sebelum jenjang pendidikan dasar ${ }^{29}$. Namun, pada jenjang pendidikan anak usia dini belum dikenalkan pendidikan agama Islam sebagai pelajaran tersendiri.

Saat ini, pendidikan agama Islam diajarkan di jenjang sekolah dasar dengan menggunakan kurikulum 2013. Perbedaan yang paling jelas pada kurikulum 2013 dengan kurikulum sebelumnya adalah sentralisasi penyusunan

${ }^{28}$ Hamlan Andi Baso Malla, "Kajian Sosio Historis Tentang Politik Kebijakan Pendidikan Islam di Indonesia" ... h. 59.

29 Dewan Perwakilan Rakyat Republik Indonesia, Undang-Undang RI Nomor 20 Tahun 2003 tentang Sistem Pendidikan Nasional, dalam Undang-Undang RI Nomor 20 Tahun 2003, Jakarta: Bp Tjipta Karya, 2013, h. 9 
buku ajar siswa. Buku ajar yang dipelajari dan dibaca oleh peserta didik disusun langsung oleh Pemerintah Pusat.

Sebagai pendamping dan penjelesan buku ajar siswa dibuatkan buku pendidik. Buku pendidik dibuat untuk mengarahkan, membimbing dan mengeksplorasi buku siswa. Hal ini tergambar dari keterangan detil langkah demi langkah yang tertuang dalam buku pendidik tersebut.

Menurut Mumpuni, penyusunan buku siswa dan buku pendidik yang diterbitkan secara sentral oleh Pemerintah Pusat adalah bentuk pengawasan isi buku. Tujuan utama pengawasan melalui penerbitan buku ini, untuk meminimalkan terjadinya ketidaksesuaian buku yang mengakibatkan bukubuku teks pelajaran ditarik ulang. ${ }^{30}$ Pendapat Mumpuni tentang sentralisasi pencetakan buku pelajaran cukup rasional. Pemerintah Pusat memang selayaknya menyediakan buku ajar sekaligus buku panduan mengajarnya karena pemerintah pusat diberikan tanggungjawab untuk itu oleh aturan yang terkait Kurikulum 2013. Pemerintah Pusat memiliki tanggungjawab atas pengawasan isi buku agar sesuai dengan harapan kurikulum. Namun, jika penerbitan buku oleh pemerintah pusat adalah untuk meminimalisir penarikan ulang akibat kesalahan adalah alasan yang cukup lemah.

Kurikulum 2013 adalah kurikulum terpusat. Pemerintah Pusat menyusun kurikulum 2013, sedangkan daerah memberikan pengayaan melalui muatan lokal. Pemerintah Pusat memiliki porsi cukup banyak dalam menentukan pelajaran yang harus dipelajari oleh peserta didik, termasuk isi dari pelajaran tersebut. Pelaksanaan Kurikulum 2013 pada jenjang sekolah dasar (SD) dilaksanakan melalui pembelajaran dengan pendekatan tematik-terpadu ${ }^{31}$ dari kelas I sampai dengan kelas VI ${ }^{32}$. Pendekatan yang yang dipergunakan untuk mengintegrasikan kompetensi dasar dari berbagai mata pelajaran yaitu intradisipliner, ${ }^{33}$ interdisipliner, ${ }^{34}$ multidisipliner, ${ }^{35}$ dan transdisipliner. ${ }^{36}$

\footnotetext{
30 Atikah Mumpuni, Integrasi Nilai Karakter dalam Buku Pelajaran: Analisis Konten Buku Teks Kurikulum 2013, Jakarta: Deepublish, 2018, h. 4

${ }^{31}$ Pembelajaran tematik terpadu adalahpembelajaran terpadu yang menggunakan tema untuk mengaitkan beberapa mata pelajaran sehingga dapat memberikan pengalaman bermakna kepada peserta didik.

${ }^{32}$ Andi Prastowo, Analisis Pembelajaran Tematik Terpadu, Jakarta: Kencana, 2019, h.1

${ }_{33}$ Intradisipliner adalah integrasi dimensi sikap, pengetahuan, dan ketrampilan secara utuh dalam setiap mata pelajaran yang diintegrasikan melalui tema.

${ }^{34}$ Interdisipliner adalah yaitu menggabungkan kompetensi dasar dari berbagai mata pelajaran agar terkait satu sama lain seperti yang tergambar pada pelajaran IPA dan IPS yang diintegrasikan pada beberapa mata pelajaran lain yang sesuai (jadi tidak ada pelajaran IPA ataupun IPS dalam struktur kurikulum)

35 Multidisipliner adalah pendekatan tanpa menggabungkan kompetensi dasar sehingga setiap mata pelajaran masih memiliki kompetensi dasarnya tersendiri.

36 Transdisipliner adalah pendekatan dalam penentuan tema yang mengaitkan berbagai kompetensi dari mata pelajaran dengan permasalahan yang ada di sekitarnya.
} 
Dalam struktur kurikulum, digambarkan adanya mata pelajaran kelompok A dan kelompok B. Mata pelajaran kelompok A adalah mata pelajaran yang kontennya dikembangkan oleh Pusat, yaitu Pendidikan Agama dan Budi Pekerti, Pendidikan Pancasila dan Kewarganegaraan, Bahasa Indonesia, Matematika, Ilmu Pengetahuan Alam dan Ilmu Pengetahuan Sosial. Adapun mata pelajaran kelompok $\mathrm{B}$ adalah mata pelajaran yang kontennya dikembangkan oleh Pusat dan dilengkapi dengan konten lokal yang dikembangkan oleh daerah. Mata pelajaran dalam kelompok B adalah Seni Budaya dan Prakarya serta Pendidikan Jasmani, Olah raga dan Kesehatan.

Mata pelajaran di SD diarahkan pada pendekatan tematik-integratif, kecuali beberapa mata pelajaran yang berdiri sendiri. Pendidikan agama, termasuk pendidikan agama Islam, adalah pelajaran yang berdiri sendiri, serupa dengan mata pelajaran pendidikan jasmani, olahraga dan kesehatan ${ }^{37}$. Sekalipun demikian, penulis menemukan bahwa buku Pendidikan Agama Islam dan Budi Pekerti (PAI-BP) ditulis dengan pendekatan multidisipliner yang diberikan selama 35 menit kali 4 (empat) jam pertemuan perpekan.

Buku siswa PAI-BP SD dicetak dengan gambar-gambar ilustrasi menarik. Sedangkan buku pendidik dicetak dengan penjelasan cukup sistematis dan memberikan arahan agar pendidik mampu mengembangkan pembelajaran. Pendidik ditempatkan pada posisi penting dalam pembelajaran menggunakan buku ini. Pendidik diharapkan untuk mampu meningkatkan dan menyesuaikan daya serap peserta didik dengan ketersediaan kegiatan yang ada pada buku ini. Pendidik diharapkan dapat memperkaya dengan kreasi dalam bentuk kegiatankegiatan lain yang bersumber dari lingkungan alam, sosial, dan budaya sekitar.

Pendidik dalam proses pembelajaran PAI-PB menggunakan buku tersebut, diharuskan mampu berperan sebagai researcher ${ }^{38}$ implementer $^{39}$, adapter ${ }^{40}$, developer $^{41}$, dan modelled $^{42}$. Peran pendidik yang demikian sentral tergambar dalam tugas pendidik yang harus memperhatikan lima hal dalam buku ini. Lima hal yang dimaksud adalah proses pembelajaran, berbagai macam penilaian pembelajaran, pengayaan bagi peserta didik yang memiliki kemampuan lebih di atas rata-rata kelas, remedial untuk peserta didik yang dipandang perlu, serta

${ }^{37}$ Farid Ahmadi dan Hamidulloh Ibda, Media Literasi Sekolah: Teori dan Praktik, Semarang, Jawa Tengah: Pilar Nusantara, 2018, h. 90

38 Researcher adalah guru yang mampu melaksanakan penelitian untuk mengetahui kekurangan dan kelebihannya dalam melaksanakan tugas, termasuk kemampuan meneliti untuk menguji efektifitas program, efektifitas startegi, efektifitas model pembelajaran, dan sebagainya.

39 Implementer adalah guru yang melaksanakan tugas sebagai pelaksana yang menerima kebijakan dan menjalankan kurikulum yang telah tersusun.

40 Adapter adalah guru yang melakukan penyelarasan kurikulum dengan karakteristik sekolah, kebutuhan peserta didik, materi dan kebutuhan daerah.

${ }^{41}$ Developer adalah guru yang mampu menyelaraskan isi, tujuan, startegi pembelajaran, dan mampu mengukur hasil belajar melalui pemilihan alat evaluasi pembelajaran.

42 Modelled adalah guru yang mampu sebagai qudwah dan uswah yaitu teladan dan contoh dalam peningkatan kompetensi peserta didik. 
interaksi antara pendidik dan orang tua peserta didik. Untuk tugas yang demikian detil dan cukup komprehensip memerlukan pendidik yang memiliki kompetensi sesuai bidang keahlian sebagai pendidik PAI.

Buku ini memuat lima kategori ruang lingkup kajian pendidikan agama Islam. Menurut Rianawati, ruang lingkup kajian pendidikan agama Islam yaitu Al-Qur'an, akidah, akhlak, fiqh/ ibadah, dan sejarah kebudayaan Islam $^{43}$. Pendapat Rianawati memerlukan kajian ulang. Pembahasan tentang fiqh atau ibadah dapat dimasukkan pada ruang lingkup akhlak, yaitu akhlak kepada Allah SWT, akhlak terhadap diri sendiri, akhlak terhadap sesama, dan akhlak terhadap lingkungan.

Dalam pembelajaran Al-Qur'an pendidik diminta untuk memberikan contoh bacaan yang benar, membimbing membaca dengan cara yang benar, menulis ulang, hingga menggali pesan ayat-ayat yang dipelajari. Adapun materi Al-Qur'an yang diajarkan adalah:

a. Kelas 1: QS. Al-Fâtihah/ 1: 1-7, Q.S Al-Ikhlâs/ 112: 1-4, huruf hijaiyah dan harakat

b. Kelas 2: QS. An-Nâs/114: 1-6, QS. Al-'Ashr/ 103: 1-3, huruf sambung

c. Kelas 3: QS. An-Nashr/ 110: 1-3, QS. Al-Kautsar/ 108: 1-3, QS. Ali-'Imran/ 3: 159, QS. Al-Isra'/ 17: 26-27, QS. Al-Baqarah/ 2: 263, QS. Al-Qamar/ 54: 17, QS. Ar-Ra'd/13: 28, QS. Al-A'raf/ 7: 55, QS. Al-Mu'min/ 40: 60.

d. Kelas 4: QS. Al-Falaq/ 113: 1-5, QS. Al-Fîl/ 105: 1-5, QS. At-Taubah/ 9: 119, QS. Luqmân/ 31: 14, QS. Al-Hadid/ 57: 9, QS. Al-'Alaq/ 96: 1-5, QS. Al-Isra'/ 17: 27 dan 37,

e. Kelas 5: QS. At-Tîn/ 95: 1-8, QS. Al-Ma'ûn/ 107: 1-7, QS. Al-Furqân/ 25: 67, QS. Al-Isra'/ 17: 27, QS. Luqman/31: 13, 17, 18

f. Kelas 6: QS. Al-Kafirûn/ 109: 1-6 (kelas 6), QS. Al-Qâri'ah/ 101: 1-11 (kelas 6), QS. Az-Zalzalah/ 99: 1-8 (kelas 6). QS. Al-Mâidah/ 5: 2-3 (kelas 6), QS. AlHujurât/ 49: 12-13 (kelas 6).

Dalam kontek mengajarkan Al-Qur'an yang demikian, pendidik hendaknya memiliki kompetensi yang sesuai. Namun, hingga saat ini belum ditemukan data yang jelas terkait dengan kompetensi guru PAI dalam mengajarkan Al-Qur'an.

Terkait materi akidah, PAI-PB dalam buku ini mengajarkan pengetahuan tentang iman kepada Allah swt dengan sifat wujud, Maha Esa, Al-Malik, dua kalimat syahadat (kelas 1), Al-khaliq dan As-Salam (kelas 2), Maha Pemberi, Maha Mengetahui, Maha Mendengar (kelas 3), Al-Bashîr, Al-'Adl, Al-Adzîm (kelas 4), Al-Mumît, Al-hayyu, Al-Qayyûm, Al-Ahad (kelas 5), As-Shamad, Al-Muqtadir, AlMuqaddim, Al-Bâqy (kelas 6). Selain pembelajaran beriman kepada Allah, buku ini juga mengajarkan beriman kepada Rasulullah, iman kepada malaikat (kelas 4),

43 Rianawati, Implementasi Nilai-Nilai Karakter pada Mata Pelajaran Pendidikan Agama Islam, Pontianak: IAIN Pontianak Press, 2014, h. 74 
iman kepada kitab suci (kelas 5), iman kepada hari akhir serta iman kepada qadha dan qadar (kelas 6).

Terkait iman kepada rasulullah, buku ini memberikan cerita singkat para nabi dan rasul. Nama-nama nabi dan rasul yang dituangkan dalam buku ini adalah Nabi Adam AS, Nabi Idris AS, Nabi Nuh AS, Nabi Hud AS (kelas 1), Nabi Shaleh AS, Nabi Ya'qub AS, Nabi Ishaq AS (kelas 2), Nabi Yusuf AS, Nabi Syu'aib AS, Nabi Ibrahim AS, Nabi Ismail AS (kelas 3), Nabi Musa AS, Nabi Ayyub AS, Nabu Dzulkifli AS, Nabi Harun AS (kelas 4), Nabi Daud AS, Nabi Sulaiman AS, Nabi Ilyas AS, Nabi Ilyasa' AS (kelas 5), Nabi Yunus AS, Nabi Zakaria AS, Nabi Yahya AS, Nabi Isa AS (kelas 6). Kajian tentang riwayat dan keteladanan Nabi Muhammad SAW ada pada setiap jenjang kelas.

Pengenalan nama-nama nabi dan rasul tampak kurang mendalam. Nabi dan rasul dikenalkan melalui sikap yang berhubungan dengan tema subbab pembahasan, misalnya nabi Daud dikenalkan sebagai sosok pemberani, nabi Yunus dikenalkan sebagai sosok yang bertanggungjawab, dan sebagainya.

Pembelajaran keimanan dengan cara mengenalkan Allah SWT, malaikat, rusul, kitab, hari akhir, dan qadla qadar secara sekilas seperti yang dipaparkan dalam buku guru maupun buku siswa, mengembangkan aspek kognitif pada tahap sensor motor. Dalam pandangan Piaget, pengembangan kognitif tahap ini masih pada level awal. Sandra Johnson menyebutkan pendapat Piaget terkait perkembangan kognisi anak. Johnson menuliskan bahwa; His theory described four stages of development: the sensorimotor stage from birth to 2 years (exploration and learning through senses and movement), pre-operational stage, 2-7 years (magical thinking, acquisition of motor skills and egocentricity), concrete operational stage 7-11 years (logical thinking begins but concrete, less egocentric), and formal operational stage, 11-16 yers and beyond (abstract reasoning and logical thinking 4 .

Jika tulisan ini diterjemahkan secara bebas maka dapat dipahami bahwa teori Piaget menggambarkan empat tahap perkembangan: tahap sensorimotor dari lahir hingga 2 tahun (eksplorasi dan pembelajaran melalui indera dan gerakan), tahap pra-operasional, 2-7 tahun (pemikiran magis, perolehan keterampilan motorik dan egosentrisitas), tahap operasional konkret 7-11 tahun (pemikiran logis dimulai tetapi konkret, kurang egosentris), dan tahap operasional formal, 11-16 tahun ke atas (penalaran abstrak dan pemikiran logis)

PAI-BP yang diajarkan melalui buku ini masih tahap sensor motor. Peserta didik diarahkan pada penguasaan obyek sebagai kekhasan obyek tersebut dan membiarkan obyek itu tetap ada walaupun bendanya sudah tidak tampak, tidak dapat dipegang. Tahap ini sudah seharusnya dilewati oleh peserta didik. Mereka selayaknya mempelajari agama Islam melalui tahapan kognisi

${ }^{44}$ Sandra Johnson, A Clinical Handbook on Child Development Paediatrics, Sydney: Elsevier, 2012, h. 3 
pada tahap kongkrit operasional. Peserta didik sudah mampu berfikir logis, konservasi $^{45}$, reversibel $^{46}$, dan identitas.

Selain pembelajaran di atas, pendidikan akhlak cukup banyak diajarkan oleh PAI-PB melalui buku-buku ini. Di kelas satu, peserta didik diajarkan kasih sayang melalui cerita kasih sayang Allah SWT dan Nabi Muhammad SAW. Mereka juga diajarkan tentang rajin belajar, berkata baik, hormat dan patuh, mensyukuri karunia pemberian, pemaaf, jujur, percaya diri. Dalam hal ibadah, peserta didik kelas satu diajarkan tata cara bersuci, shalat wajib, dan mengaji di lingkungan sekitar.

Pendidikan akhlak terhadap sesama menjadi penekanan yang sangat mendasar dan mengambil porsi besar dalam PAI-BP ini. Sikap-sikap sosial seperti peduli lingkungan, kerjasama, tolong menolong, kasih sayang sesama (kelas 2), tanggungjawab, tawaddu', peduli sesama, bersyukur (kelas 3), rendah hati, hemat, gemar membaca, pantang menyerah, hormat dan patuh, menghargai teman, santun (kelas 4), hidup sederhana, ikhlas, saling menghargai, hormat dan patuh orang tua dan guru, hidup sederhana dan ikhlas (kelas 5), tanggungjawab, kasih sayang, patuh, taat, peduli, serta teguh pendirian (kelas 6). Sikap sosial di atas digambarkan melalui cerita-cerita rusul, orang shalih, dan walisongo.

Pembelajaran PAI-PB ini memenuhi standar pembelajaran yang tersistematis. Menurut Oemar Hamalik, standar pembelajaran tersistematis memuat rencana, kesalingtergantungan (interdependence), dan tujuan ${ }^{47}$. Upaya melalukan pembelajaran dengan sistematika terstruktur demikian hendaknya diimbangi dengan kompetensi pendidik PAI-PB sesuai standar. Kemampuan pendidik bukan sekedar kemampuan menyampaikan materi pelajaran. Keberhasilan pendidikan di kelas membutuhkan suasana yang mendukung. Oleh karena itu, pembelajaran dengan cara damai (penetration pacifique) sangat menunjang keberhasilannya ${ }^{48}$.

PAI-PB saat ini memberikan porsi lebih banyak pada pendidik. Pendidik terlibat dalam merencanakan, melaksanakan, dan melakukan penilaian terhadap proses pembelajaran PAI-BP. Pendidik diharuskan mampu memahami setiap bab yang berisi kompetensi inti, kompetensi dasar, tujuan pembelajaran, proses

45 Peserta didik sudah mampu memahami aturan. Misalanya, mereka telah menyadari bahwa jumlah ataupun volume benda tidak berubah jika tidak ada penambahan maupun pengurangan, selain perubahan bentuk atau perubahan ketentuan.

46 Peserta didik mempu memahami bahwa terdapat hal yang dapat dibalik. Contoh paling sederhana unutk memahami reversibelitas adalah operasi penjumlahan, $2+7=9$ atau $9-2=7$; contoh dalam konteks pembelajaran PAI, peserta didik usia sekolah dasar dapat diajarkan cara berbakti kepada orang tua dengan cara memahamkan peran orang tua dan anak melalui film-film pendek tentang proses kelahiran hewan.

47 Oemar Hamalik, Kurikulum dan Pembelajaran, Jakarta: Bumi Aksara, 2017, h. 66

48 Akhmad Shunhaji, "Islamic Religion Education Implementation in Catholic School Blitar City, East Jawa and the Impact on Participants of Social Interaction, dalam journal iiste, vol 9 No 36, 2018, https://www.iiste.org/Journals/index.php/JEP/article/view/45784 
pembelajaran, penilaian, pengayaan, remedial, dan interaksi antara pendidik dan orang tua. Pendidik juga harus mampu memahami karakteristik peserta didik untuk dapat melakukan proses pembelajaran, penilaian, pengayaan, dan remedial yang tepat.

Sistematika demikian memungkinkan peserta didik mengalami capaian hasil pembelajaran PAI-PB dalam lima hal. Pertama, peserta didik mampu mengamalkan praktik ibadah di masa depan sesuai dengan pengalaman belajar yang dilalui. Kedua, peserta didik memperoleh pengetahuan tambahan tentang PAI-PB sesuai pengalaman belajarnya. Ketiga, peserta didik memandang pendidik sebagai orang yang memiliki pengetahuan dan pengamalan agama lebih baik. Keempat, peserta didik menjadi pribadi pasif dalam menggali pendalaman ilmu agama Islam. Kelima, suasana belajar PAI-PB terbatas pada pembelajaran di kelas.

\section{KESIMPULAN}

Berdasarkan kajian terhadap buku pendidikan agama Islam (PAI) dan budi pekerti (BP), corak agama Islam pada jenjang sekolah dasar dapat disimpulkan sebagai berikut:

Pertama, Pendidikan Agama Islam bercorak Islam moderat. Peserta didik diajak untuk mempelajari ajaran Islam yang santun dalam menyikapi banyak hal.

Kedua, Peserta didik diajarkan PAI pada lingkup akhlak terhadap sesama lebih besar porsinya dibanding dengan akidah, al-Qur'an, sejarah kebudayaan Islam, serta akhlak kepada Allah SWT, diri sendiri, dan lingkungan alam.

Ketiga, Pendidik diposisikan sebagai pribadi yang memahami dan memiliki wawasan luas tentang Al-Qur'an dan ajaran-ajaran Islam dasar yang akan diajarkan. Pendidik juga diposisikan sebagai pribadi yang paham terhadap pengembangan potensi peserta didik, sumber-sumber belajar, dan membentuk lingkungan kondusif untuk belajar. Dengan kompetensi demikian, pendidik diharapkan mampu menjaga orisinalitas akidah, kreatif, memiliki wawasan luas, mampu memanfaatkan budaya dan kekayaan alam lokal.

Keempat, Penilaian terhadap perkembangan penguasaan sikap spiritual dan sikap sosial peserta didik masih perlu pengembangan. Penilaian sikap spiritual dan sikap sosial masih perlu penjelasan yang lebih mendalam, karena penilaian yang telah disediakan masih dominan pada aspek pengetahuan dan ketrampilan. Artinya, porsi penilaian sikap spiritual dan sikap sosial yang seharusnya diperankan oleh pendidik PAI-PB masih relatih sedikit. 


\section{DAFTAR PUSTAKA}

Ahmadi, Farid dan Hamidulloh Ibda, Media Literasi Sekolah: Teori dan Praktik, Semarang, Jawa Tengah: Pilar Nusantara, 2018.

Dewan Perwakilan Rakyat, Undang-undang RI Nomor 2 Tahun 1989 tentang Sistem Pendidikan Nasional, dalam Undang-undang RI Nomor 2 Tahun 1989, Jakarta: Bp Tjipta Karya, 1989.

Dewan Perwakilan Rakyat, Undang-Undang Sistem Pendidikan Nasional Nomor 20 Tahun 2003, dalam Undang-Undang Sistem Pendidikan Nasional, Jakarta: Permata Press, 2013.

Haligan dan Turner, Profile of Government Administration in Asia, Canberra: Australia Government Publishing Service, 1995.

Hamalik, Oemar, Kurikulum dan Pembelajaran, Jakarta: Bumi Aksara, 2017.

Johnson, Sandra, a Clinical Handbook on Child Development Paediatrics, Sydney: Elsevier, 2012.

Maarif, Ahmad Syafi'i, Islam dan Politik: Teori Belah Bambu Masa Demokrasi Terpimpin 1959-1965, Jakarta: Gema Insani, 1996.

Majelis Permusyawaratan rakyat, Panduan Pemasyarakatan Undang-Undang Dasar Negara Republik Indonesia Tahun 1945, Jakarta: Sekretariat Jenderal MPR RI, 2006.

Malla, Hamlan Andi Baso, "Kajian Sosio Historis Tentang Politik Kebijakan Pendidikan Islam di Indonesia", Inspirasi, Nomor XIV Edisi Oktober 2011.

Mas'ud, Abdur Rahman dan A.Salim Ruhana, Kompilasi Kebijakan dan Peraturan Perundang-Undangan Kerukunan Umat beragama, Edisi ke-11, Jakarta: Puslitbang Kehidupan Keagamaan, 2009.

Mastuhu, Menata Ulang Pemikiran Sistem Pendidikan Nasional dalam Abad 21, Yogyakarta: SIP dan MSI UII, 2003.

Menteri Sekretaris Negara, Lembaran Negara: "Penetapan Presiden Republik Indonesia Nomor 19 Tahun 1965" Tentang Pokok-Pokok Sistem Pendidikan Nasional Pancasila, dalam dapp.bappenas.go.id, diakses pada tanggal 14 Oktober 2019.

Mohtar, Imam, Problematikan Pembinaan Pendidikan Agama Islam pada Masyarakat, Ponorogo: Uwais Inspirasi Indonesia, 2017.

Mumpuni, Atikah, Integrasi Nilai Karakter dalam Buku Pelajaran: Analisis Konten Buku Teks Kurikulum 2013, Jakarta: Deepublish, 2018.

Palmer, Joy A. (ed), 50 Pemikir Pendidikan: dari Piaget sampai Masa Sekarang, diterjemahkan oleh Farid Assifa dari judul Fifty Modern Thinkers on Education, Yogyakarta: Jendela, 2003.

Prastowo, Andi Prastowo, Analisis Pembelajaran Tematik Terpadu, Jakarta: Kencana, 2019.

Rianawati, Implementasi Nilai-Nilai Karakter pada Mata Pelajaran Pendidikan Agama Islam, Pontianak: IAIN Pontianak Press, 2014. 
Roberts, Keith A., Religion in Sociological Perspective, Fifth Edition, USA: SAGE Publications, Inc, 2012.

Shunhaji, Akhmad, "Islamic Religion Education Implementation in Catholic School Blitar City, East Jawa and the Impact on Participants of Social Interaction, dalam journal iiste, vol 9 No 36, 2018, https://www.iiste.org/Journals/index.php/JEP/article/view/45784

------, Implementasi Pendidikan Agama di Sekolah Katolik Kota Blitar dan Dampaknya terhadap interaksi Sosial, Yogyakarta: Aynat Publishing, 2017.

Umar, Nasaruddin, Antara Negara dan Agama, dalam www.kemenag.go.id diakses pada tanggal 16 Oktober 2019.

Widiyanto, Nur, Revisi Kurikulum 2013, guru lebih dimudahkan, dalam www.kemdikbud.go.id diakses pada tanggal 14 Oktober 2019. 